\title{
A CONSTITUIÇÃo HiSTÓRICA DO CAMPO PSICOLÓGICO EM SUA DISPERSÃO
}

\author{
Aline Gabriela Simon \\ Ana Luiza de Britto Silva, \\ Felipe Alves Fonseca \\ Paula Rego-Monteiro Marques Vieira \\ Sara Costa Cabral Mululo \\ Paulo Cardoso Ferreira Pontes ${ }^{\star}$ \\ Arthur Arruda Leal Ferreira ${ }^{\star \star}$
}

Palavras-chave: História da Psicologia. Práticas Sociais. Filosofia da Psicologia.

Este trabalho foi apresentado no IV CONPSI (Congresso Norte-Nordeste) em maio de 2005 - Salvador - Bahia.

O objetivo deste trabalho é tentar compreender a dispersão presente no campo psicológico, explicando porque orientações e práticas tão diversas se sustentam, seja através de um conjunto de práticas sociais, seja através das transformações no campo dos saberes modernos. Utilizamos para isso a análise de fontes primárias (textos clássicos da psicologia) e secundárias (autores que entendem a psicologia a partir de um conjunto de experiências e práticas sociais). Duas questões podem ser colocadas quando se busca demarcar a história da Psicologia: qual seria sua origem histórica, e em que período ela se constituiria como saber? Historiadores clássicos vão privilegiar uma constituição remota da Psicologia, no século XIX, onde sua história se confundiria com a própria história do pensamento ocidental. Uma outra perspectiva pensa a psicologia, irrompendo desde o século XVI, a partir de múltiplas raízes entrelaçadas de experiências, que levariam à busca de uma natureza na interioridade e na individualidade humanas. Entendemos, portanto, que a psicologia teria surgido de várias orientações e experiências diversificadas, que, reordenadas, formariam o mosaico que constitui o campo psicológico. Estas experiências foram tomadas aqui a partir de dois eixos principais: 1) A experiência que constitui uma região de interioridade nos indivíduos, existente segundo Foucault (1984) desde as práticas de confissão cristãs, e que a partir do século XIX, com Kant (1871), passa a ser fundamentada por um transcendental incognoscível. A psicologia passaria a esta-

^ Graduandos do Instituto de Psicologia da UFRJ.

$\star \star$ Professor do Instituto de Psicologia da UFRJ, Doutor em Psicologia Clínica pela PUC-SP, pesquisador financiado pela FAPERJ e FUJB (UFRJ), orientador do trabalho. Residente na Rua do Riachuelo 169/405. Centro - Rio de Janeiro - RJ. CEP: 20.230-014.

E-mail: arleal@ superig.com.br 
belecer uma relação entre o sujeito empírico (nossas experiências conscientes) e um sujeito transcendental (conceitos emprestados de outros saberes). Ora partindo das experiências a uma explicação transcendental, ora chegando à experiência consciente através de um conceito de outro saber; 2) A experiência de individualização, que constrói, no século XVI, um indivíduo autônomo, sendo "fonte" contratual dos Estados modernos, que Foucault (1976) chama de indivíduo soberano; e um indivíduo enquanto objeto disciplinado, sendo "alvo" do cuidado dos Estados contemporâneos. Esta experiência marcaria toda a prática psicológica, oscilando entre a busca da autonomia e do controle de seus sujeitos. Outras experiências modernas estariam articuladas à construção de um espaço de interioridade e de uma individualidade nos sujeitos. Seriam experiên-cias variadas, como a que se opera entre corpo e mente (sugerida por Descartes e discutida pela psicologia do século XVIII), Razão e Loucura (descrita por Foucault em A História da Loucura), idade adulta e infância (desenvolvida por Philippe Áries, na História Social da Criança e da Família), e domínio público e privado (Norbert Elias, $O$ processo civilizador). Uma última questão merece ser colocada: como se dá a cientifização dessas experiências? Para Foucault, em As Palavras e as Coisas, foram necessárias, para isso, uma série de transformações no conhecimento que possibilitaram o surgimento de uma ciência do homem no século XIX. O homem como ser empírico é descortinado como objeto natural pelas ciências empíricas e reduplicado em sujeito como fundamento pelas filosofias antropológicas, e a psicologia surgiria do cruzamento desses movimentos. Seriam, então, estas hibridações entre os conceitos científicos, os conceitos filosóficos e as práticas sociais descritas, que possibilitaram a constituição do campo fragmentado da psicologia.

Agências Financiadoras: FAPERJ e FUJB. 